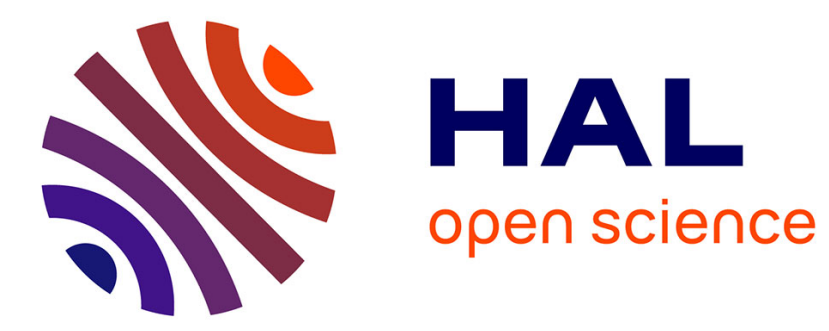

\title{
Calibration of SCIAMACHY Using AATSR Top-of-Atmosphere Reflectance Over a Hurricane
}

Olivier Jourdan, Alexander A Kokhanovsky, John Burrows

\section{To cite this version:}

Olivier Jourdan, Alexander A Kokhanovsky, John Burrows. Calibration of SCIAMACHY Using AATSR Top-of-Atmosphere Reflectance Over a Hurricane. IEEE Geoscience and Remote Sensing Letters, 2007, 4 (1), pp.8 - 12. 10.1109/lgrs.2006.881726 . hal-01893578

\section{HAL Id: hal-01893578 https://hal.science/hal-01893578}

Submitted on 22 Jan 2021

HAL is a multi-disciplinary open access archive for the deposit and dissemination of scientific research documents, whether they are published or not. The documents may come from teaching and research institutions in France or abroad, or from public or private research centers.
L'archive ouverte pluridisciplinaire HAL, est destinée au dépôt et à la diffusion de documents scientifiques de niveau recherche, publiés ou non, émanant des établissements d'enseignement et de recherche français ou étrangers, des laboratoires publics ou privés. 


\title{
Calibration of SCIAMACHY
}

\section{using AATSR top-of-atmosphere reflectance over a hurricane}

\author{
O. Jourdan (1,2), A. A. Kokhanovsky(1), J. P. Burrows(1)
}

(1) Institute of Environmental Physics, University of Bremen, D-28334 Bremen, Germany

(2) Now at, Laboratoire de Météorologie Physique (LaMP), Université Blaise Pascal, Clermont-Ferrand, France

\begin{abstract}
This letter investigates the synergy between SCIAMACHY (Scanning Imaging Absorption Spectrometer for Atmospheric ChartographY) and AATSR (Advanced Along Track Scanning Radiometer) onboard the ENVISAT platform for reflectance calibration purpose. This calibration study was mainly performed over a portion of a hurricane corresponding to fully cloudy SCIAMACHY and AATSR pixels. Results show that SCIAMACHY underestimates the top of atmosphere (TOA) reflectance by up to $23 \%$ (at 870nm) as compared to AATSR for a nadir viewing geometry. Specifically, considering AATSR calibration as accurate, which is confirmed by comparison with MERIS (Smith, 2005), the SCIAMACHY top-of-atmosphere reflectances should be multiplied by 1.21 , $1.19,1.23$, and 1.10 for wavelengths at $550 \mathrm{~nm}, 670 \mathrm{~nm}, 870 \mathrm{~nm}$, and $1600 \mathrm{~nm}$, respectively, ahead of satellite retrieval schemes based on the measurements of TOA reflectance.
\end{abstract}

Key words: satellite instrumentation, calibration, AATSR, MERIS, SCIAMACHY 


\section{Introduction : Overview of SCIAMACHY calibration issue}

The SCAnning Imaging Absorption spectroMeter for Atmospheric ChartographY (SCIAMACHY) is a moderate resolution imaging spectrometer (Bovensmann et al., 1999) onboard ENVISAT. It is designed to measure the scattered and reflected spectral radiance in nadir and limb geometry, the spectral radiance transmitted through the atmosphere (solar and lunar occultation geometry) and the extraterrestrial solar irradiance and the lunar radiance. It was launched on orbit on March $1^{\text {st }}$, 2002. Measurements are expected to continue for at least another four years (till 2010). Data are recorded at moderate spectral resolution (0.2-1.5nm) in a spectral range of 240-1750 nm divided in 6 channels as well as in two smaller spectral regions corresponding to 1940-2040nm and 2265-2380nm. In the nadir mode, the spatial resolution is between $30 \times 30 \mathrm{~km}^{2}$ and $30 x 240 \mathrm{~km}^{2}$. Accordingly, SCIAMACHY's main objective is focused on the accurate measurements of trace gases in the terrestrial atmosphere. As most SCIAMACHY retrieval algorithms rely on studies of the depths of gaseous absorption bands of backscattered solar light (Borell et al., 2004), the accurate calibration of the instrument is not of primary importance. However, for the retrieval of the atmospheric optical thickness (OT) from space, an accurate calibration is essential. Indeed, for optically thin atmospheric layers, radiative transfer calculations show that the optical thickness is directly proportional to the top-of-atmosphere (TOA) reflectance. Therefore, calibration errors of, for example 25\%, will produce in turn the same range of error for OT (for optically thin layers). The uncertainties in the forward model can increase the error even further or make the retrievals impossible (e.g., the aerosol TOA reflectance can become a negative number after removal of a well-defined molecular scattering contribution). 
Numerous studies have been performed related to SCIAMACHY calibration, both reanalyzing ground data collected before launch of ENVISAT (Noël, 2005) and also using the comparison with the MEdium Resolution Imaging Spectrometer (MERIS) TOA reflectances (Acarreta and Stammes, 2005; Kokhanovsky et al., 2006a; von Hoyningen-Huene et al., 2006).

MERIS is a $68.5^{\circ}$ field-of-view pushbroom imaging spectrometer that measures the solar radiation reflected by the Earth, at a ground spatial resolution of $300 \mathrm{~m}$, in 15 spectral bands, programmable in width and position, in the visible and near infra-red. MERIS allows global coverage of the Earth in 3 days. The reduced resolution mode (RRM) of MERIS has a spatial resolution of $1040 \mathrm{~m}$ across track and $1160 \mathrm{~m}$ along track. Measurements are performed in nadir geometry in 15 narrow channels with an average spectral width of 10nm (Bezy et al., 2000; von Hoyningen-Huene et al., 2006) ${ }^{1}$. Moreover, Delwart et al. (2004) showed that the calibration error of MERIS was below $4 \%$.

The analysis performed by several groups confirmed that TOA reflectances measured by SCIAMACHY are too low as compared to MERIS measurements. Previous works emphasized that SCIAMACHY calibration errors vary from 10 to $25 \%$ depending on the channel and the ground reflectance conditions (see among others, Kerridge et al., 2002; Latter et al., 2003; Acaretta and Stammes, 2005; Noël, 2005; von HoyningenHuene et al., 2006). Although there are physical grounds behind the possible changes of the error with the wavelength (e.g., due to the spectral reflectance of films and coatings on the optics of an instrument), the calibration factors should not depend on the surface

\footnotetext{
1 More specifically, the channels are centered on the following wavelengths : $412.5 \mathrm{~nm}(10 \mathrm{~nm})$, $442.5 \mathrm{~nm}(10 \mathrm{~nm}), 490 \mathrm{~nm}(10 \mathrm{~nm}), 510 \mathrm{~nm}(10 \mathrm{~nm}), 560 \mathrm{~nm}(10 \mathrm{~nm}), 620 \mathrm{~nm}(10 \mathrm{~nm}), 665 \mathrm{~nm}(10 \mathrm{~nm})$, 681.3nm(7.5nm), 708.8nm(10nm), 753.8nm(7.5nm), 760.6nm (3.8nm), 778.8nm(15nm), 865nm (20nm), $885 \mathrm{~nm}(10 \mathrm{~nm}), 900 \mathrm{~nm}(10 \mathrm{~nm})$ where the width of the correspondent channel is given in brackets.
} 
reflection. However, comparisons between SCIAMACHY and MERIS measurements showed that significant differences of reflectances were encountered between these two instruments depending on the surface type. The biases were always found to be larger for underlying water surfaces. In particular, Acarreta and Stammes (2005) found that the difference with MERIS was only of $15 \%$ over land but $25 \%$ over ocean for the $885 \mathrm{~nm}$ wavelength. We believe that such an estimation of the calibration error is more reliable over an ocean surface because the surface contribution is less important at $885 \mathrm{~nm}$ for ocean compared to that of the land. It also should be pointed out that the bi-directional properties of the surface and its horizontal inhomogeneity may influence the main assumption of a vicarious calibration:

$$
\bar{R}=\int R(r) d r
$$

for sensors having significantly different spatial resolutions. In Eq. (1), $\bar{R}$ is the reflectance measured by a sensor having a coarse spatial resolution ( $\sim 2000 \mathrm{~km}^{2}$ in the case of SCIAMACHY) and $R(r)$ is the reflectance measured by an instrument with a high spatial resolution (e.g., $\sim 1 \mathrm{~km}^{2}$ as in the case of MERIS) at the point characterized by the two dimensional radius-vector $r$. Furthermore, the violation of Eq. (1) can be also due to discrepancies in observation angles of instruments under comparison. Under condition that Eq. (1) holds, results of Acarreta and Stammes (2005) assert that the calibration factor indeed depends on the ground scene, being systematically smaller for bright surfaces (in the 442-885nm wavelength range). On the other hand, as we mentioned above, due to the linearity of detectors, the bias between MERIS and SCIAMACHY calibration factors shouldn’t depend significantly of the scene studied. It points out that the relationship presented in Eq. (1) does not hold for all cases. 
Therefore, it is more adequate to perform a calibration study over a homogeneous surface or to use wavelengths where the surface contribution is low.

In order to address further the SCIAMACHY calibration issue, we have performed the vicarious calibration of SCIAMACHY over a hurricane with an underlying ocean surface, using yet another optical instrument on ENVISAT, namely the Advanced Along Track Scanning Radiometer (AATSR). This is considered in the next section.

\section{Vicarious calibration of SCIAMACHY using AATSR TOA reflectance}

AATSR, along with MERIS and SCIAMACHY, is part of the atmospheric payload onboard ENVISAT. AATSR employs a dual view where each scene is viewed at nadir and at a forward angle of $55^{\circ}$. Its field of view covers a $512 \mathrm{~km}$ width curved swath centered at nadir and the ground pixel size is $1 \times 1 \mathrm{~km}^{2}$ at the center of the nadir scan. The spectral information of the sensor is divided in three thermal infrared channels centered at 3.7 $\mu \mathrm{m}, 11 \mu \mathrm{m}$ and $12 \mu \mathrm{m}$ and four visible/near infrared channels (20-nm width except for a channel $60 \mathrm{~nm}$ wide centered at $1.6 \mu \mathrm{m}$ ) centered at $0.55 \mu \mathrm{m}, 0.67 \mu \mathrm{m}, 0.87 \mu \mathrm{m}$ and 1.6 $\mu \mathrm{m}$. According to SCIAMACHY spectral resolution, these four channels can directly be exploited for TOA reflectances comparison between SCIAMACHY and AATSR. Additionally, the calibration error of AATSR is small and comparable with that of MERIS. The differences in MERIS-AATSR TOA reflectances are close to $+3 \%$ for wavelengths at $0.55 \mu \mathrm{m}$, and $0.87 \mu \mathrm{m}$, and below $1 \%$ at $0.665 \mu \mathrm{m}$ (Smith, 2005).

Considering the calibration issues stated earlier, we chose to make a comparison of AATSR-SCIAMACHY reflectances over a scene with an underlying ocean surface that mainly encompasses optical thick cloud fields. In particular, this case study was 
conducted over Hurricane Isabel (orbit 08094 of ENVISAT, 17.09.2003, 14:50UTC) with a center located at $(72 \mathrm{~W}, 30 \mathrm{~N})$ (Fig.1). One can refer to our previous work (Kokhanovsky et al., 2006b) for further details on the selected scene. SCIAMACHY Level 1 productsversion 5 wereused in this work.

The AATSR-SCIAMACHY reflectances intercomparison methodology follows the same procedure as the one proposed by Acarreta and Stammes (2005). First, the four visible/near infrared AATSR channels $(0.55 \mu \mathrm{m}, 0.67 \mu \mathrm{m}, 0.87 \mu \mathrm{m}$ and $1.6 \mu \mathrm{m})$, which are within SCIAMACHY spectral range, were selected. Then, in order to compare L1 AATSR nadir products with L1 SCIAMACHY products, spectrally averaged nadir reflectances are calculated for SCIAMACHY at each AATSR visible/near infrared spectral channels by integrating over AATSR filter response function. The shape of the AATSR slit function was chosen as a rectangular one. We believe that the choice of such a shape will not introduce significant errors compared to the real AATSR filter response function as Acarreta and Stammes (2005) found that the effect of the MERIS slit function was negligible on the change of the calibration factors. Additionally, the spectral dependence of the reflection function of cloudy scenes is negligible due to the large size of scatterers. The final step consisted in collocating $1 \times 1 \mathrm{~km}^{2}$ AATSR pixels within each 30x60 $\mathrm{km}^{2}$ SCIAMACHY pixels on the basis of their longitude and latitude coordinates. Additionally, in this study, only SCIAMACHY pixels corresponding to a cloud fraction greater than $99 \%$ were selected. This pixel selection was based on a threshold technique of the SCIAMACHY and AATSR TOA reflectances at $0.87 \mu \mathrm{m}$. An AATSR pixel within a given SCIAMACHY pixel has been considered as completely cloudy if the reflection function at $0.87 \mu \mathrm{m}$ of both instruments exceeded the threshold value of 0.2 
(Kokhanovsky and von Hoyningen-Huene, 2004). In turn, the number of AATSR cloudy pixels within the SCIAMACHY pixel gives an estimation of the cloud cover of the SCIAMACHY pixel. The pixels fulfilling these criteria were used to investigate the possibility to establish linear relationships between SCIAMACHY and AATSR reflectances and therefore perform a calibration study.

We believe that a scene containing a hurricane structure is a good choice for the vicarious calibration of SCIAMACHY, not only because the levels of backscattered light intensity on SCIAMACHY detectors are quite large and variable, but also due to the relative homogeneity of the spectral TOA reflection function (RF). Additionally, the RF of the thick clouds under study is only slightly dependant on the observation angles and wavelengths. This reduces the possible influence of the observation geometry and the spectral instrument sensitivity function on the calibration coefficient. The possible effects of the surface inhomogeneity and the lower troposphere also significantly diminish for this case.

The results of the AATSR-SCIAMACHY reflectances intercomparison are presented in terms of linear regression plots displayed for four wavelengths in Figs. 2-5. It follows from the analysis of Figs. 2-5, that AATSR reflectances $\left(R_{\text {aatsr }}\right)$ and SCIAMACHY reflectances $\left(\mathrm{R}_{\text {scia }}\right)$ are almost perfectly correlated with a correlation coefficient larger than $98 \%$. The least square fit error is close to 0.01 for each wavelength and the offset has a maximum value of 0.004 indicating that overall the fit is acceptable.

However, $R_{\text {scia }}$ are lower by $21 \%$ at $550 \mathrm{~nm}, 19 \%$ at $670 \mathrm{~nm}, 23 \%$ at $870 \mathrm{~nm}$, and $10 \%$ at $1600 \mathrm{~nm}$ as compared to $R_{\text {aatsr }}$. This is close to earlier MERIS-based findings reported above. Moreover, the calibration coefficient $C=R_{\text {aatsr }} / R_{\text {scia }}$ at $870 \mathrm{~nm}$ is equal to 1.23 
which is in close agreement with the value $C=1.25$ reported by Acarreta and Stammes (2005) at 885nm for MERIS measurements over ocean. Results of the vicarious calibration using AATSR compared to the one reported by Acarreta and Stammes (2005) are presented in Table 1. It ensues from this table that MERIS and AATSR give comparable calibration coefficients with respect to SCIAMACHY. We chose not to report the offset in our table because it represents a low reflectance value and can be neglected. This is confirmed by other independent calibration studies (Acarreta and Stammes, 2005; von Hoyningen-Huene et al., 2006). Results for calibration coefficients obtained using the comparison of SCIAMACHY measurements with those of POLDER instrument (see http://smsc.cnes.fr/POLDER/ for the description of the instrument) have been presented by Tilstra and Stammes (2006). They are also given in Table 1. The calibration coefficients found are consistent with previous findings reported by Acarreta and Stammes (2005) obtained using MERIS.

It follows that $C$ generally increases with the wavelength except the case at $1600 \mathrm{~nm}$, where the calibration error is at minimum $(C=1.1)$. The similar trend is seen in the analysis of ground SCIAMACHY calibration data as reported by Noël (2005) ${ }^{2}$ (doted points on Fig. 6). This behavior was also found by von Hoyningen-Huene et al. (2006), who determined, using MERIS observations, values of $C$ equal to 1.10, 1.12, 1.21 for SCIAMACHY channels 3 (394-620nm), 4(604-805), and 5(785-1050), respectively.

Figure 6 displays the spectral dependence of SCIAMACHY calibration factors obtained from measurements carried out at ground before launch of ENVISAT (open circles) and derived from MERIS (full black squares), AATSR (open triangles), and

\footnotetext{
${ }^{2}$ Refer to the following web page for further details : http://www.iup.physik.uni-bremen.de/sciamachy/SCIA_CAL/rad_cal.html and also Fig.6
} 
POLDER (stars) data. The calibration coefficients represented by open circles in Fig.6 (except highly oscillating results at the edge of SCIAMACHY channels) will be used in the next version of SCIAMACHY Processor (the version 6.0, S. Noël, private communication). In this way, after this re-calibration is achieved, MERIS and SCIAMACHY will have very similar reflectances at 442 and 510nm. The reflectance of SCIAMACHY for other wavelengths will also come closer to the results obtained by other instruments. However, except at 1600nm, the SCIAMACHY reflectances will remain on average smaller than those of MERIS and AATSR.

In a previous work, Kerridge et al. (2002) compared SCIAMACHY and AATSR reflectances for several heterogeneous ground scenes. In total, five scenes were analyzed and both SCIAMACHY and AATSR reflectances were averaged over larger scenes of $480 * 512 \mathrm{~km}^{2}$. They found calibration coefficients equal to 1.13 (at 550nm), 1.10 (at $670 \mathrm{~nm}$ ), and 1.19 (at $870 \mathrm{~nm}$ ). The coefficient found at $870 \mathrm{~nm}$ is in agreement with the one reported by us and also to that obtained using MERIS (see Table 1). The coefficients at smaller wavelengths are smaller than the ones we found but remain closer to those corresponding to average coefficients obtained from MERIS observations. This could be explained by the fact that coefficients reported by Kerridge et al. (2002) and also by Acarreta and Stammes (2005) correspond to highly heterogeneous scenes (e.g., water, vegetation, clouds). Our results characterize a somehow more homogeneous scene encompassing a hurricane. However our results still remain comparable with MERIS observations over water surfaces. Yet another possible reason of differences could come from the fact that previous AATSR-SCIAMACHY calibration studies were limited to scenes with lower reflectivity compared to the case studied in this paper. 
Latter et al. (2003) found that the calibration coefficients are 1.15 (at 550nm), 1.05 (at 670nm), 1.24(at $870 \mathrm{~nm}$ ), and 1.13 (at 1600nm). They have also used AATSR for SCIAMACHY calibration based on the analysis of three complete orbits. However, instead of averaging AATSR pixels to the SCIAMACHY $30 * 60 \mathrm{~km}^{2}$ scenes, much larger ground scenes were selected.

\section{Conclusions}

We confirm that the current version of SCIAMACHY Processor (5.0) underestimates the TOA reflectance. The comparison of SCIAMACHY with AATSR measurements over a hurricane points out an underestimation of TOA reflectances by SCIAMACHY of $21 \%, 19 \%, 23 \%$, and $10 \%$ at $550,670,870$, and $1600 \mathrm{~nm}$, respectively, which is generally consistent with findings of Acarreta and Stammes (2005) using MERIS. Kerridge et al. (2002) used a similar approach as described in this paper and found calibration differences for SCIAMACHY around 13\% (550nm), 10\%(670nm), and $19 \%(870 \mathrm{~nm})$ as compared to AATSR with a small variability depending on the scene studied. Latter et al. (2003) reported the values of $15 \%$ (550nm), $5 \%(670 \mathrm{~nm})$, 24\%(870nm), and 13\%(1600nm) comparing AATSR and SCIAMACHY collocated measurements. The discrepancies of calibration constants reported by different authors could be due to the differences in the ground scenes and versions of processors used. Although there is a discrepancy with respect to the derived value of the SCIAMACHY calibration constants by different remote sensing groups, the underestimation of SCIAMACHY TOA reflectances can be considered as a well established fact now. Therefore, we conclude that it is of importance to introduce the next version of 
SCIAMACHY processor as soon as possible in order to enable aerosol and cloud retrievals from SCIAMACHY measurements.

Clearly, because ENVISAT is planned to be in operation at least till 2010, more calibration efforts for SCIAMACHY will be needed in future (e.g., using Moon as a light source for calibration). This new re-calibration may remove small - scale oscillations present in the latest version of the calibration curve given in Fig.6.

\section{Acknowledgements}

This work has been supported by Alexander von Humboldt Foundation and DFG Project BU-688-2. Authors are grateful to B. Latter, R. Neil, S. Noël, D. L. Smith, P. Stammes, and W. von Hoyningen-Huene for a number of discussions related to the calibration issues of AATSR, MERIS, and SCIAMACHY. 


\section{References}

Acarreta, J. R., and P. Stammes, 2005: Calibration comparison between SCIAMACHY and MERIS onboard ENVISAT, IEEE Geosci. Rem. Sens. Letters, 2, 31 - 35.

Bezy, J. L., S. Delwart, and M. Rast, 2000: MERIS - a new generation of ocean-colour sensor onboard ENVISAT, ESA Bulletin, 103, 48-56.

Borrell, P., P. M. Borrell, J. P. Burrows, and U. Platt, (Eds.), 2004: Sounding the Troposphere from Space. A New Era for Atmospheric Chemistry, Berlin: Springer.

Bovensmann, H., J. P. Burrows, M. Buchwitz, J. Frerick, S. Noël, V. V. Rozanov, K. V. Chance, and A. P. H. Goede, 1999: SCIAMACHY: Mission objectives and measurement modes, J. Atmos. Sci., 56, 127-150.

Delwart, S., L. Bourg, and J. P. Hout, 2004: MERIS 1st year: early calibration results, Proc. SPIE, 5234, 379-390.

Kerridge, B., R. Siddans, J. Reburn, B. Latter, and V. Jay., 2002: Intercomparison of MIPAS and SCIAMACHY L1 and L2 products with GOME and AATSR, Proc. ENVISAT Validation Workshop, Frascati, Italy, December 9-13.

Kokhanovsky, A. A., and W. von Hoyningen-Huene et al., 2004: Optical properties of a hurricane, Atmos. Res., 69, 165-183.

Kokhanovsky, A. A. , W. von Hoyningen-Huene, V. V. Rozanov, et al., 2006a: The semianalytical cloud retrieval algorithm for SCIAMACHY. II. The application to MERIS and SCIAMACHY data, Atmos. Chem. Phys. Discussions, 6, 1813-1840.

Kokhanovsky, A. A., O. Jourdan, and J. P. Burrows, 2006b: The cloud phase discrimination from a satellite, IEEE Trans. Geosci. Rem. Sens., Letters, 3, 103-106. 
Latter, B., R. Siddans, B. J. Kerridge., 2003: Intercomparison of reflectances observed by SCIAMACHY, GOME, AATSR, ATSR-2, Geophys. Res. Abstracts, 5, 30-1-2003.

Noël, S., 2005: Determination of correction factors for SCIAMACHY radiances and irradiances, University of Bermen, Germany, Technical Report, IFE-SCIA-SN20050203_IrrRadCorrection. The report is available at the following website:

http://www.iup.physik.uni-bremen.de/sciamachy/SCIA_CAL/irrad_corr.pdf.

Smith, D. L., 2005: Intercalibration of AATSR and MERIS reflectances, Proc. of the MERIS(A)ATSR Workshop 2005, Frascati, Italy, 26-30 September (ESA SP-597, December 2005).

Tilsra, G., P. Stammes, 2006: Level 1-1 calibration study: SCIAMACHY versus POLDER, Proceedings of Atmospheric Science Conference, Frascati: May 8-12, 2006.

von Hoyningen-Huene, W., A. A. Kokhanovsky, M. W. Wuttke, et al., 2006: Validation of SCIAMACHY top-of-atmosphere reflectance for aerosol remote sensing using MERIS L1 data, Atmos. Chem. Phys. Discussions, 6, 673-699. 
Table 1. The values of the calibration coefficient $\mathrm{C}$ averaged for different ground scenes

\begin{tabular}{|l|l|l|}
\hline$\lambda, \mathrm{nm}$ & \multicolumn{1}{|c|}{$\mathrm{C}$} & \multicolumn{1}{c|}{ Reference } \\
\hline 442 & 1.13 & Acarreta and Stammes (2005) (ocean:1.18) \\
\hline 443 & 1.12 & Tilstra and Stammes (2006) (POLDER) \\
\hline 490 & 1.13 & Tilstra and Stammes (2006) (POLDER) \\
\hline 510 & 1.13 & Acarreta and Stammes (2005) (ocean:1.17) \\
\hline 550 & 1.21 & this work \\
\hline 565 & 1.14 & Tilstra and Stammes (2006) (POLDER) \\
\hline 665 & 1.15 & Acarreta and Stammes (2005) (ocean:1.19) \\
\hline 670 & 1.19 & this work \\
\hline 708 & 1.18 & Acarreta and Stammes (2005) (ocean: 1.21) \\
\hline 765 & 1.16 & Tilstra and Stammes (2006) (POLDER) \\
\hline 870 & 1.23 & this work \\
\hline 885 & 1.21 & Acarreta and Stammes (2005) (ocean:1.25) \\
\hline 910 & 1.21 & Tilstra and Stammes (2006) (POLDER) \\
\hline 1600 & 1.10 & this work \\
\hline
\end{tabular}


Figure captions

Fig. 1 Browse image of Hurricane Isabel as seen by AATSR.

Fig.2 Correlation between AATSR and SCIAMACHY reflectances at 550nm.

Fig.3 The same as in Fig.2 except at 670nm.

Fig.4 The same as in Fig.3 except at 870nm.

Fig.5 The same as in Fig.2 except at 1600nm.

Fig.6 Spectral dependence of the calibration factor measured at ground (Noel, 2005) and also using AATSR, MERIS and POLDER. Bars show the estimated MERIS calibration error of 4\% (Delwart et al., 2004). The difference in calibrations of MERIS and AATSR are $\quad$ smaller than 3\% with the overestimation by AATSR (Smith, 2005). 


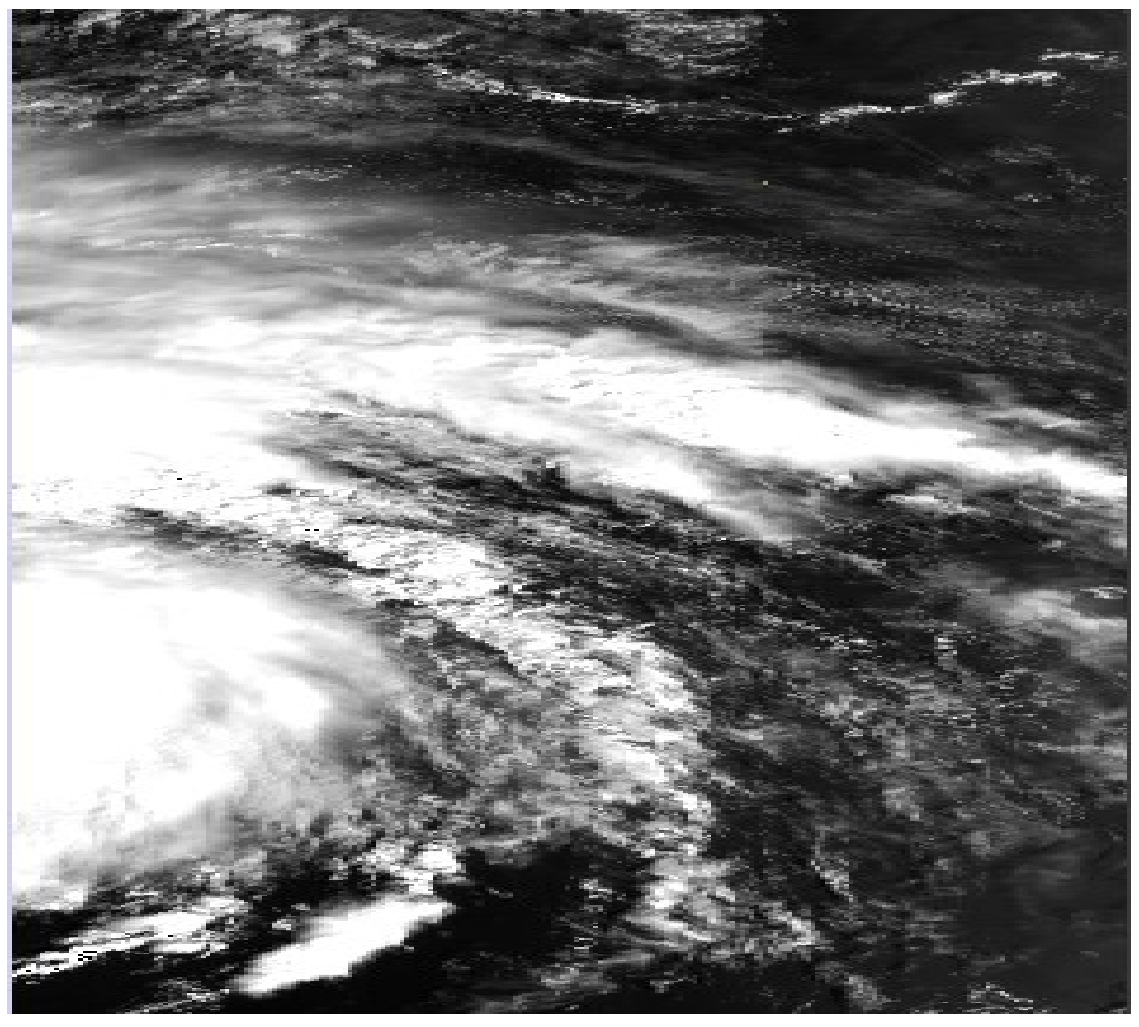

Fig.1 


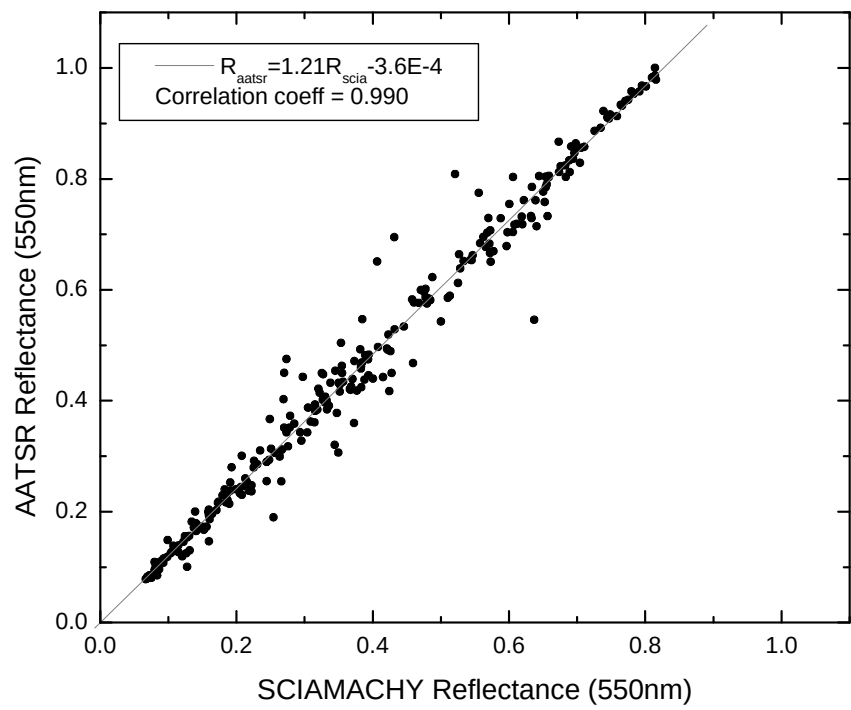

Fig.2 


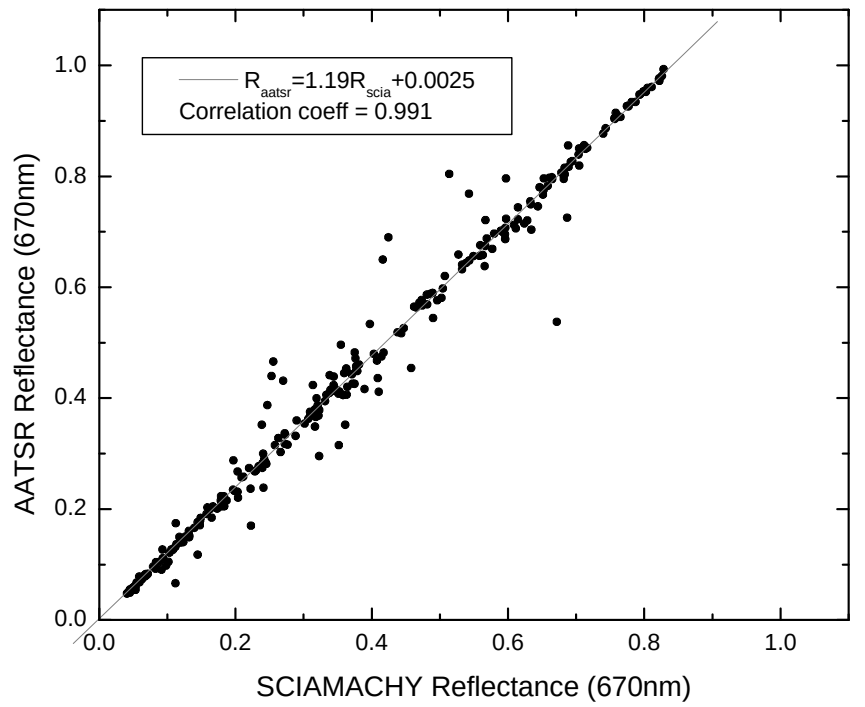

Fig.3 


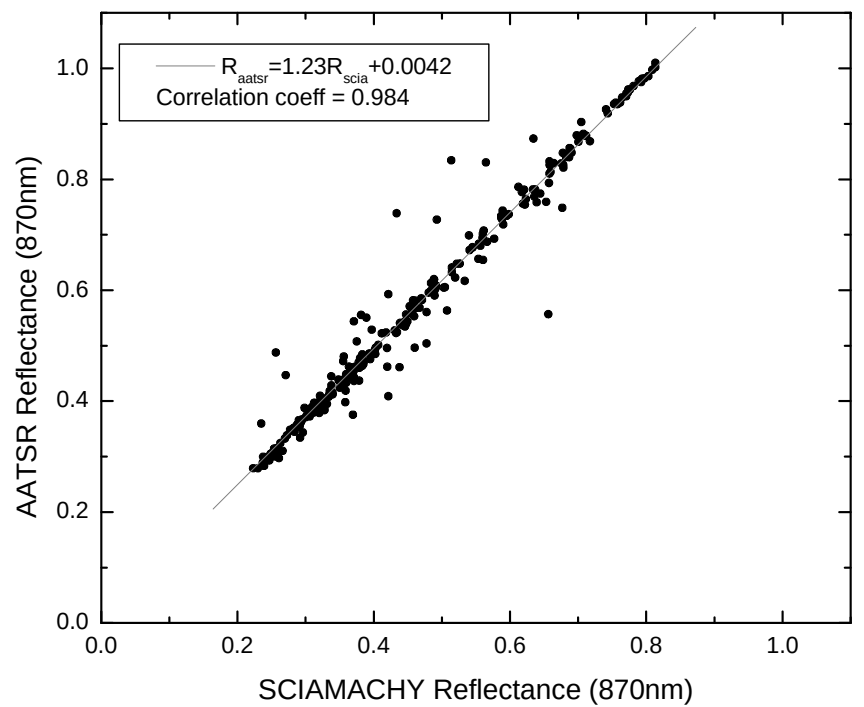

Fig.4 


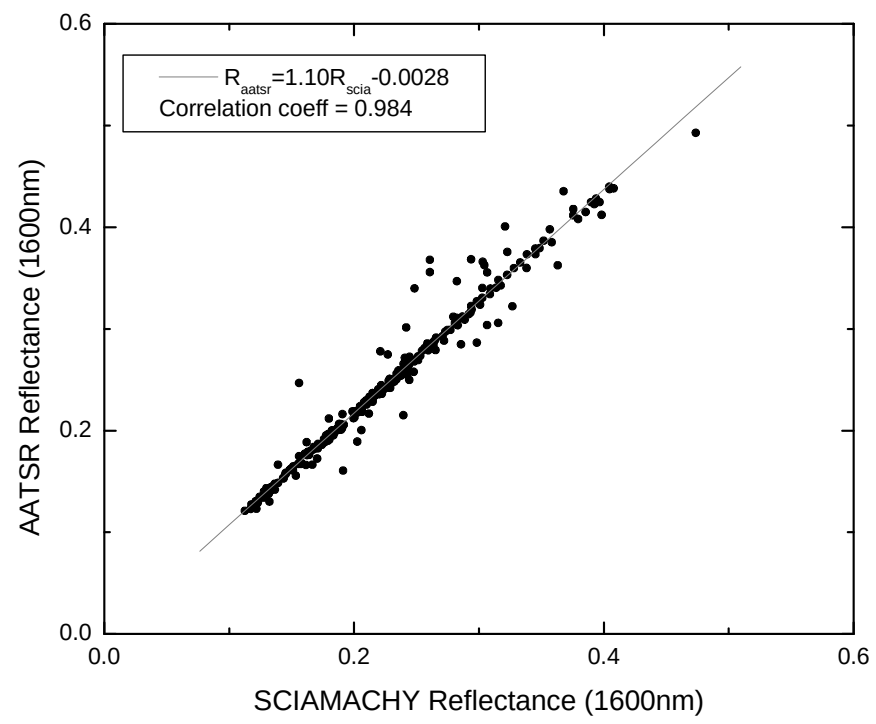

Fig.5 


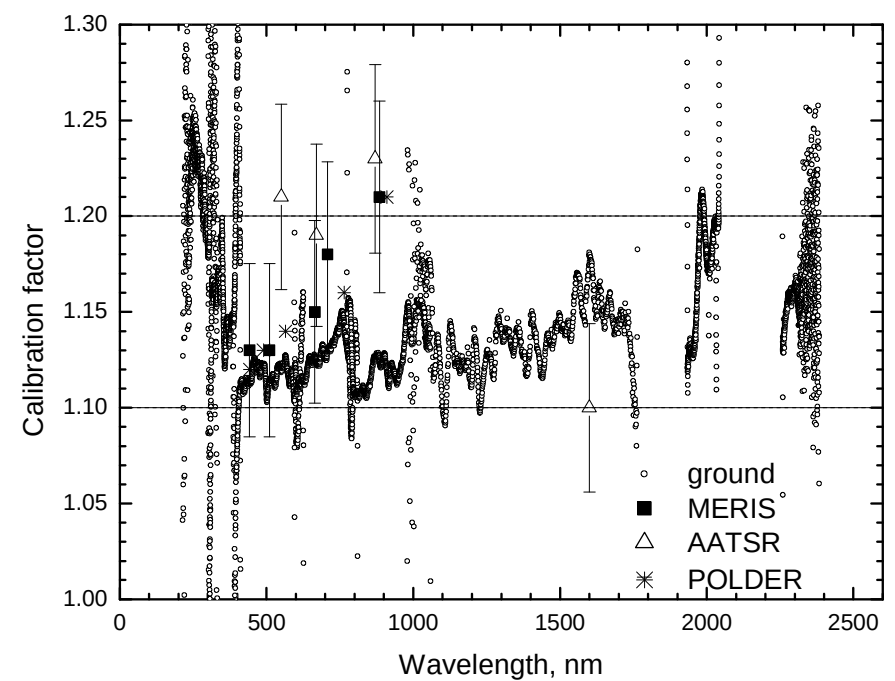

Fig.6 